\title{
PENGABDIAN MASYARAKAT: UPAYA MENGHINDARI STROKE PADA IBU RUMAH TANGGA BERUSIA 30 TAHUN KE ATAS
}

\section{Nita Noriko ${ }^{1^{*}}$, Firli Azkia Rahmi ${ }^{1}$, Adienda Yoesmah Zhafirah ${ }^{\mathbf{1}}$, Astria Prastika Dewi Clarinda Puspitajati ${ }^{1}$, Zahid azka Ramadhan ${ }^{1}$}

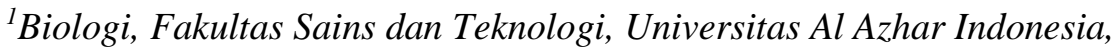 \\ Jalan Sisingamangaraja, Kompleks Masjid Agung Al Azhar, Kebayoran Baru, Jakarta 12110 \\ Email Penulis Korespondensi:nita_noriko@uai.ac.id
}

\begin{abstract}
Abstrak
Stroke merupakan ancaman kesehatan yang dapat disebabkan berbagai faktor diantaranya tekanan sistol dan diastol, gula darah, asam urat dan kolestrol darah di atas normal. Sangat disayangkan pada umumnya ibu rumah tangga tidak memahami dan kurang perhatian terhadap kondisi kesehatannya khususnya kualitas makanan yang dikonsumsi. Oleh sebab itu diperlukan penyuluhan mengenai cara menghindari stroke dan pemeriksaan kesehatan diperlukan oleh para wanita. Metode yang digunakan adalah survei kondisi kesehatan berupa pemeriksaan darah dan penyuluhan terhadap wanita berusia 30 tahun ke atas yang selanjutnya dikelompokkan 2 kelompok. Kelompok pertama adalah wanita yang berusia 30-50 tahun dan kelompok kedua di atas 50 tahun. Kegiatan pengabdian kepada masyarakat dilaksanakan di salah satu RT di Lampiri, Pondok Kelapa, Jakarta Timur. Hasil pemeriksaan pada pertemuan pertama menunjukkan bahwa tekanan darah sistol wanita usia 30-50 tahun berbeda nyata dengan yang berusia > 50 tahun ( $p<0,05$ ) yaitu 147,00/90,11 $\mathrm{mmHg}$ dan 155,1429/84.4286 $\mathrm{mmHg}$. Asam urat, kolestrol dan gula darah sebelum penyuluhan menunjukkan batasan angka normal, kecuali gula darah wanita di atas usia 50 tahun. Wawasan yang diberikan kepada masyarakat pada pertemuan adalah tentang makanan sehat dan gaya hidup untuk melindungi ancaman stroke. Pengukuran tekanan sistol pada pertemuan 2 menunjukkan penurunan yaitu dari 140,9655/82,68 mm Hg menjadi 134,1500/81,30 mm Hg. Kesimpulan dari pengabdian masyarakat tersebut adalah penyuluhan dan deteksi kesehatan perlu dilanjutkan secara periodik.
\end{abstract}

Kata kunci: Asam urat, Diastol, Gula darah, Kolestrol, Pengabdian masyarakat, Sistol, Stroke

\begin{abstract}
Stroke is a health threat that was caused by several factors such as systole and diastole pressure, blood glucose, uric acid above normal. However usually housewives not aware of their health especially the quality of their food were consumed. Counseling how to avoid from stroke and detected health housewife are important. The goals of the public service were to offer the preventive strategy from stroke protection. The Methodology was a survey of health condition especially blood pressure, cholesterol, uric acid, and blood glucose and health care counseling to women more than 30 years old which divided into two groups. First group was women 30-50 years old dan the second group more than 50 years old. The public service program conducted in one of RT in Lampiri Pondok Kelapa East Jakarta. The result indicated in the first meeting systole of the women 30-50 years old were higher and significantly different with > 50 years old $(p$ 0,05), there were 147,00/90,11 mm $\mathrm{Hg}$ and 155,1429/84,4286 mm Hg. Uric acid, cholesterol, and blood glucose before counseling showed normal in women 30-50 years old and abnormal in > 50 years old women. The topic of counseling was healthy food and lifestyle to preventive the stroke attack. The second meeting systole showed decreasing from 140,9655/82,68 $\mathrm{mm} \mathrm{Hg}$ to 134,1500/81,30 $\mathrm{mm} \mathrm{Hg}$. The conclusion of public service is counseling and detection of health have to continue in periodic time.
\end{abstract}

Keyword: Uric acid, Diastole, Blood glucose, Choleserol, Public service, Cystole, Stroce 


\section{PENDAHULUAN}

Daerah Lampiri Pondok Kelapa Jakarta Timur termasuk daerah perkotaan yang padat huni. Areal hijau untuk penyerapan air, lahan berkumpul dan bermain anak di pemukinam penduduk sulit ditemukan sehingga hanya mengandalkan fasilitas umum seperti Ruang Publik Terbuka Ramah Anak (RPTRA). Wilayah ini juga dilalui oleh jalur transportasi perkotaan yaitu tol Becakayu dan jalan lintas antar kelurahan sehingga daerah ini terasa panas dan bising.

Wilayah tersebut didominasi oleh masyarakat urban yang tinggal di rumah sewa. dengan sirkulasi udara yang tidak lancar. Ruangan rumah kurang mendapat sinar matahari yang cukup sehingga menyebabkan kondisi pengap. Aliran air kotor juga tidak terkontrol dan dibuang keselokan dengan drainase yang kurang lancar. Status rumah sewa membuat warga tidak memperhatikan jarak yang ideal antara jamban dan penyediaan air bersih dari tanah.

Kondisi ekonomi masyarakat di wilayah tersebut tergolong menengah kebawah dengan tingkat pendidikan terakhir didominasi oleh lulusan SMP. Pekerjaan wanita berusia antara 30 sampai 50 tahun adalah sebagai ibu rumah tangga dengan pekerjaan tambahan seperti berjualan sayuran, kue-kue tradisional seperti lontong, goreng pisang, bakwan, menjadi pembantu rumah tangga dan pengawai laundry yaitu sebagai pencuci dan penyetrika pakaian. Pekerjaan wanita di atas 50 tahun adalah mengurus rumah tangga dan cucu di rumah. Kepala keluarga umumnya menjadi supir mikrolet dan ojek, berjualan, teknisi bengkel, buruh bangunan.

Kecukupan kebutuhan makanan masih terbatas dengan konsumsi harian sebagai sumber protein adalah telur, ayam, dan ikan asin, tahu dan tempe. Sumber karbohidrat sehari-hari selain nasi adalah mie instant. Sumber serat, vitamin dan mineral umumnya sayur dan buah-buahan. Daya dukung untuk kehidupan masih terbatas untuk memenuhi konsumsi sehari-hari dan tempat tinggal.

Kondisi lingkungan seperti ini dapat menimbulkan penurunan kesehatan. Khususnya wanita yang berperanan penting dalam pengelolaan rumah tangga perlu dilindungi kesehatannya. Kasus penyakit yang yang dihadapi masyarakat perkotaan telah bergeser dari penyakit menular ke penyakit tidak menular seperti stroke yang menurunkan kualitas hidup dan kematian. Stroke merupakan penyebab kematian nomor tiga dan kecacatan nomor satu di seluruh dunia dengan presentase $80 \%$ sampai 85\% (Hafid, 2014). Menurut WHO pada tahun 2011 Indonesia telah menempati peringkat ke-97 dunia untuk jumlah penderita stroke terbanyak dengan jumlah angka kematian mencapai 138.268 orang atau $9,70 \%$ dari total kematian yang terjadi pada tahun 2011. Diperkirakan setiap tahunnya sekitar 500.000 orang penduduk Indonesia terkena stroke, dengan angka kematian sebesar $25 \%$ atau sekitar 125.000 orang yang meninggal dan sisanya mengalami cacat berat maupun ringan (Minarti Manurung, 2015). Di Indonesia, penderita stroke semakin meningkat, hal ini menyebabkan beban bagi negara bertambah akibat disabilitas yang ditimbulkannya (Lannywati Ghani, 2016).

Berdasarkan hasil Riskesdas tahun (2013) jumlah penyakit stroke di Indonesia meningkat seiring bertambahnya usia. Pada usia 75 tahun keatas mencapai $43,1 \%$ dan terendah pada kelompok usia 15-24 tahun sebesar 0,2\%. Berdasarkan jenis kelamin lebih banyak lakilaki yaitu $7,1 \%$ dibandingkan dengan perempuan $6,8 \%$. Berdasarkan tempat tinggal prevalensi stroke diperkotaan 8,2\% dibandingkan dengan daerah pedesaan 5,7\%.

Stroke merupakan suatu penyakit yang disebabkan karena adanya gangguan pada pembuluh darah atau pecahnya pembuluh darah di otak yang mengakibatkan terganggunya suplay darah ke otak sehingga menyebabkan nekrosis sel-sel otak akibat tidak adaya asupan nutrisi dan oksigen dari darah (Manurung, 2015). Suplai darah yang tidak memadai disebabkan oleh pengecilan diameter pembuluh darah yang disebabkan oleh penebalan plak yang berasal dari penumpukan kolesterol jenis LDL yang akhirnya meningkatkan resiko gangguan cardiometabolik. Resiko stroke juga ditemui pada penderita diabetes mellitus (Tun dkk, 2017). Pada pasien dengan LDL, kolesterol, dan trigliserida di atas normal berkaitan dengan prevalensi hyperuricemia (Mehrpour, dkk 2012).

Stroke dapat timbul secara tiba-tiba atau mendadak dengan progres cepat, yang ditandai dengan defisit neurologis lokal maupun global yang dapat menyebabkan kematian Stroke dapat menyerang berbagai usia, laki-laki, dan perempuan. Penyakit stroke terus mengalami peningkatan seiring dengan perubahan gaya hidup yang memengaruhi seperti perubahan 
pola makan, dan pola hidup yang jarang melakukan olahraga (Sulansi, 2015). Selain itu pemicu penyakit stroke dapat disebabkan oleh faktor usia, hipertensi, diabetes, paparan asap rokok, displidemia dan pola hidup yang tidak sehat.

Sosialisasi dalam bentuk pengabdian masyarakat untuk memberikan informasi serta pemahaman kepada masyarakat mengenai bahaya penyakit stroke, upaya meningkatkan kesadaran masyarakat dalam menjalani pola hidup sehat, dan faktor penyebab stroke sangat diperlukan.

\section{Tujuan}

Kegiatan ini bertujuan untuk memberikan informasi serta pemahaman mengenai upaya preventif terhadap bahaya stroke dan meningkatkan perhatian masyarakat khususnya wanita berusia di atas 30 tahun terhadap kesehatan.

\section{METODE PELAKSANAAN}

Pengabdian masyarakat dilakukan pada hari Minggu, 14 Januari 2018 dan 25 Maret 2018. Kegiatan dimulai pada pukul 9.00 WIB sampai dengan 13.00 WIB. Lokasi dilakukan pngabdian masyarakat ini di Lampiri Pondok Kelapa Jakarta Timur. Sasaran pengabdian masyarakat adalah kaum ibu berusia 30 tahun ke atas.

Kegiatan ini diawali dengan melakukan pemeriksaan darah dan tekanan secara langsung. Pemeriksaan darah yang dilakukan meliputi pengukuran gula darah, asam urat, dan kolesterol. Kegiatan dilanjutkan dalam bentuk penyuluhan mengenai penyebab dan upaya preventif untuk menghindari stroke. Jadwal kegiatan terdapat pada Tabel 1.

\section{Cara kerja pemeriksaan darah dan pengukuran tekanan darah}

Pengukuran tekanan darah dengan cara melilitkan manset tensi ke bagian lengan atas kiri. selanjutnya tekan tombol start dan lihat angka pada indikator sistol dan diastol yang ada pada tensi meter. Pengukuran gula darah, asam urat, dan kolsterol yang dilakukan menggunakan Accu Chek GCU (Glucose, Cholesterol, and Uric acid), check softclick, strip GCU, dan alkohol swab. Pertama yang dilakukan adalah mengusap salah satu jari menggunakan alkohol swab, kemudian darah diambil menggunakan check softclik dan darah yang telah keluar masing-masing diteteskan pada strip (gula darah, kolesterol, dan asam urat) sebanyak 1-2 tetes dan pada Accu check akan terdapat angka.

Tabel 1. Kegiatan Pengabdian masyarakat

\begin{tabular}{|c|c|c|}
\hline Hari dan Tanggal & Waktu & Kegiatan \\
\hline \multirow{4}{*}{ Minggu, 14 Januari 2018} & $9.00-9.30$ & Persiapan \\
\hline & $9.30-10.30$ & $\begin{array}{l}\text { Penyuluhan, mengenai: } \\
\text { - Stroke } \\
\text { - Penyebab stroke } \\
\text { - Pengolahan stres dengan pendekatan } \\
\text { - Pencegahan stroke }\end{array}$ \\
\hline & $10.30-12.00$ & $\begin{array}{l}\text { Pemeriksaan kondisi kesehatan yang meliputi pengukuran } \\
\text { tekanan darah, gula darah, kolesterol, dan asam urat }\end{array}$ \\
\hline & $12.30-13.00$ & Konsultasi kesehatan dan pembagian makanan sehat \\
\hline \multirow{3}{*}{ Minggu, 25 Maret 2018} & $13.00-13.30$ & Persiapan \\
\hline & $13.30-14.30$ & $\begin{array}{l}\text { Penyuluhan, mengenai: } \\
\text { - } \quad \text { Kehiatan yang dapat mengurangi stres dan meningkatkan } \\
\text { kualitas lingkungan } \\
\text { - } \quad \text { Demo kegiatan-kegiatan untuk mengurangi stres }\end{array}$ \\
\hline & $14.30-15.00$ & Pemeriksaan tekanan darah \\
\hline
\end{tabular}




\section{HASIL DAN PEMBAHASAN}

Jumlah wanita yang mengikuti pemeriksaan kondisi kesehatan untuk menghindari stroke pada pertemuan pertama adalah 29 orang, sedangkan yang ke dua adalah 21 orang. Hal ini disebabkan pada pertemuan ke 2 ada kegiatan pengajian di wilayah setempat yang diikuti oleh warga. Antusias para ibu sangat tinggi untuk memperhatikan penyuluhan dan pemeriksaan kesehatan khususnya darah seperti yang terdapat pada Gambar 1. Umumnya masyarakat yang mengikuti kegiatan ini sudah mengetahui indikasi stroke dalam perspektif awam seperti kesulitan berbicara, wajah yang tidak simetris, bagian tubuh yang sulit digerakkan namun tidak mengetahui penyebabnya. Pengetahuan ini dapat disebabkan oleh masyarakat yang sering menemukan dalam kehidupan sehari-hari anggota keluarga maupun relasinya yang menderita penyakit tersebut. Pada kegiatan pengabdian masyarakat dijelaskan mengenai faktor penyebab stroke yang mudah dimonitor melalui alat deteksi yang sederhana yaitu pengukuran tekanan darah, asam urat, dan gula darah.

Pengukuran tekanan darah yang dapat bandingkan pada wanita berusia 30-50 tahun adalah 9 orang dengan usia di atas 50 tahun adalah 7 orang. Hasil pengukuran tekanan darah sistol, diastol, asam urat, kolesterol menunjukkan perbedaan yang nyata antara wanita berusia 30 sampai 50 tahun dengan usia di atas 50 tahun $\mathrm{p}<0,05$. Tekanan sistol pada rata-rata wanita usia $\geq 50$ tahun lebih tinggi yaitu $155,1429 \mathrm{mmHg}$ dibandingkan dengan wanita berusia 30-50 tahun yaitu $147 \mathrm{mmHg}$.

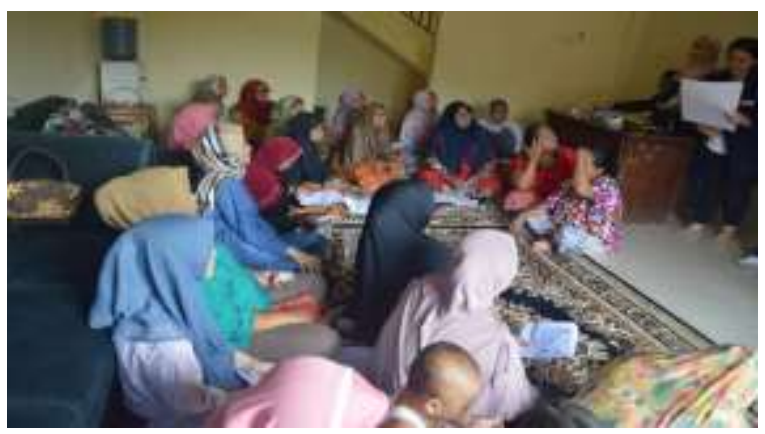

Gambar 1. Antusias para ibu mendengarkan penyuluhan

Perbedaan yang signifikan $\mathrm{p}<0,05$ juga terdapat pada tekanan darah diastol rata-rata pada wanita berusia $30-50$ adalah $90,11 \mathrm{mmHg}$ sedangkan pada peserta berusia diatas 50 tahun
$84,42 \mathrm{mmHg}$. Hasil pengukuran tekanan darah wanita tanpa memperhatikan usia rata-rata sebelum penyuluhan adalah 140,9655/82,68 $\mathrm{mmHg}$. Tekanan darah tersebut tergolong tinggi terutama sistol di atas normal. Hipertensi sistol disebabkan pola makan yang tinggi mengkonsumsi garam dan natrium. Menurut Kozier et al (2010) kondisi tersebut dapat juga disebabkan oleh penurunan elastisitas arteri terutama pada usia setelah menapause

Hasil wawancara menjelaskan bahwa para ibu yang mengikuti pengabdian masyarakat setiap hari umumnya mengkonsumsi makanan dengan kadar garam $(\mathrm{NaCl})$ yang tinggi seperti seperti ikan asin. Selain itu makanan yang mengandung $\mathrm{Na}$ tingggi seperti mie instant dan junk food. Natrium dapat mempengaruhi volume darah yang diikuti dengan peningkatan tekanan darah. Faktor lain adalah adanya kemungkinan pemakaian hormon pencegah kehamilan (kontrasepsi). Perubahan tekanan darah disebabkan adanya pengaruh hormon gonadotropin dan hormon progesterone. Efek ke dua hormon tersebut menyebabkan jantung memompa lebih kuat, arteri besar. Hipertensi yang disebabkan faktor eksternal ini termasuk hipertensi sekunder (Lanny dkk, 2004).

Berikut ini adalah foto yang menunjukkan antusisme seluruh para ibu melakukan pemeriksaan darah dan mengkonsultasikan hasil pemeriksaannya (Gambar 2).

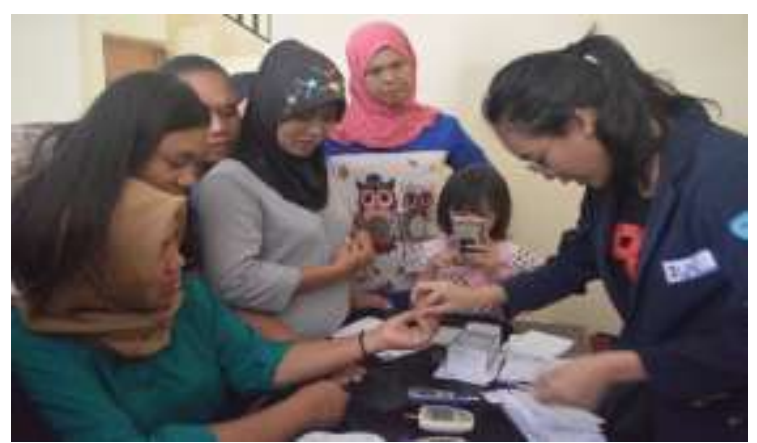

Gambar 2. Kesadaran yang tinggi dari para ibu untuk melakukan pemeriksaan darah

Korelasi positif antara sistol dan diastol menunjukkan 0,613 artinya, semakin besar nilai sistol maka diastolnya akan semakin tinggi begitu juga sebaliknya. Korelasi sistol dengan gula darah dan asam urat, memiliki nilai korelasi yang rendah.

Respon para ibu yang menghadapi masalah tekanan darah yang tinggi setelah memperoleh informasi mengenai faktor pemicu stroke/penyuluhan sangat tinggi. Hal ini 
ditunjukkan dengan motivasi untuk berkonsultasi dengan mahasiswa seperti yang ditunjukkan pada Gambar 3 dan Gambar 4 Seluruh ibu-ibu peserta yang mengikuti program pengabdian masyarakat berkonsultasi untuk memperoleh anjuran untuk menurunkan tekanan darah

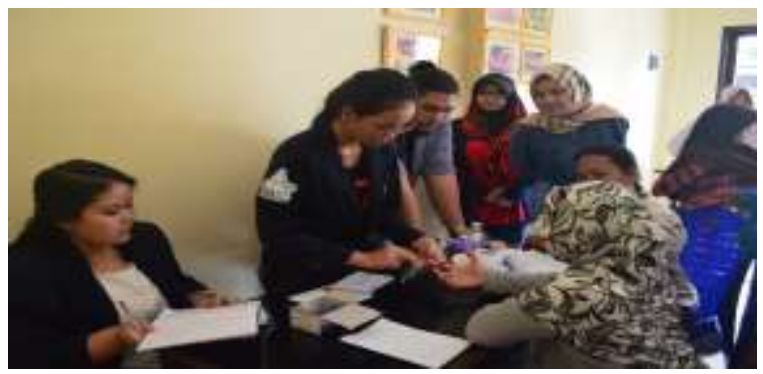

Gambar 3. Para ibu berkonsultasi mengenai upaya untuk mrnurunkan tekanan darah yang tinggi

Data gula darah rata-rata lebih pada para ibu yang berusia 30 sampai 50 tahun tergolong normal yaitu $107,555 \mathrm{mmol} / \mathrm{L}$, akan tetap setelah menginjak usia $\geq 50$ tahun menunjukkan peningkatan yaitu di atas normal 181,2857 mmol/L. Hal ini dapat disebabkan karena penurunan penurunan sensitivitas jaringan terhadap insulin pada usia di ats 50 tahun (Touchette 2005).

Kadar asam urat rata-rata pada wanita berusia 30 sampai 50 tahun menunjukkan angka 6,1778 mgDL yang berusia diatas 50 tahun memiliki rata-rata kadar asam urat sebanyak 5,3714 $\mathrm{mg} / \mathrm{dl}$. Hal ini terjadi kemungkinan karena pada berusia diatas 50 tahun pada umumnya sudah mulai ada keluhan reumatik sehingga berusaha untuk menghindari makanan yang menimbulkan keluhan.

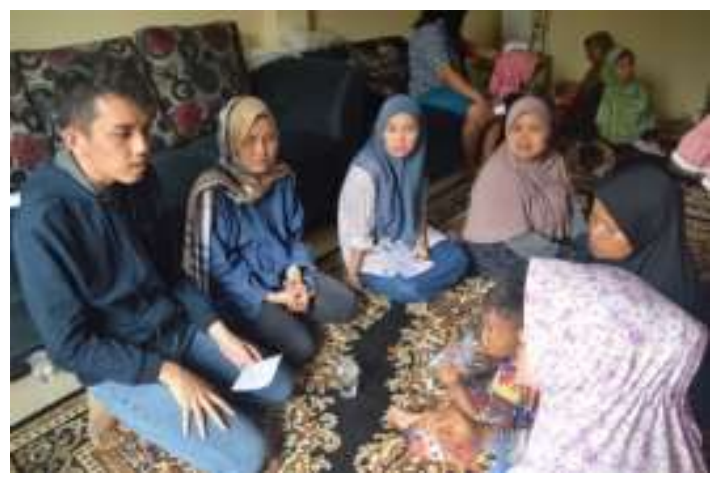

Gambar 4. Para ibu berkonsultasi mengenai hasil pemeriksaan darah

Tabel 2. Kondisi Kesehatan dari Aspek tekanan darah, gula darah, asam urat dan kolestrol

\begin{tabular}{|c|c|c|c|c|}
\hline No. & Faktor & Usia & $\mathrm{N}$ & Mean \\
\hline \multirow[t]{2}{*}{1} & Tekanan darah sistol & $30-50$ tahun & 9 & $\begin{array}{c}147,0000 * \mathrm{~mm} \\
\mathrm{Hg}\end{array}$ \\
\hline & & $\geq 50$ tahun & 7 & $155,1429 * \mathrm{mmHg}$ \\
\hline \multirow[t]{2}{*}{2} & Tekanan darah diastol & $30-50$ tahun & 9 & $\begin{array}{c}90,1111 * \mathrm{~mm} \\
\mathrm{Hg}\end{array}$ \\
\hline & & $\geq 50$ tahun & 7 & $84,4286 \mathrm{mmHg}$ \\
\hline \multirow[t]{2}{*}{3} & Gula Darah & 30 - 50 tahun & 9 & $\begin{array}{c}107,5556 \\
\mathrm{mmol} / \mathrm{L}\end{array}$ \\
\hline & & $\geq 50$ tahun & 7 & $\begin{array}{c}181,2857 \\
\mathrm{mmol} / \mathrm{L}\end{array}$ \\
\hline \multirow[t]{2}{*}{4} & Asam Urat & $30-50$ tahun & 9 & $6,1778 \mathrm{mg} / \mathrm{DL}$ \\
\hline & & $\geq 50$ tahun & 7 & $5,3714 \mathrm{mg} / \mathrm{DL}$ \\
\hline \multirow[t]{2}{*}{5} & Kolesterol & 30- 50 tahun & 9 & $\begin{array}{c}\text { 199,1111 } \\
\mathrm{mg} / \mathrm{DL}\end{array}$ \\
\hline & & $\geq 50$ tahun & 7 & $\begin{array}{c}183,7143 \\
\mathrm{mg} / \mathrm{DL}\end{array}$ \\
\hline
\end{tabular}

Keterangan : ${ }^{*}=$ Tekanan darah tinggi 
Faktor-faktor yang mempengaruhi asam urat di atas normal menurut Choi (2005) antara lain adalah makanan dengan kadar purin tinggi seperti jeroan, daging baik daging sapi, babi, kambing atau makanan dari hasil laut (sea food), kacang-kacangan, bayam, jamur, kembang kol, sarden, kerang, minuman beralkohol. Pemeriksaan lain yang diikuti oleh masyarakat adalah kandungan kolesterol darah. Hasil pemeriksaan rata-rata wanita berusia 30 sampai 50 tahun memiliki adalah $199,1111 \mathrm{mg} / \mathrm{Dl}$, dan di atas 50 tahun rata-rata $183,7143 \mathrm{mg} / \mathrm{DL}$. Angka tersebut termasuk normal Kondisi ini terjadi karena makanan yang dikonsumsi umumnya rendah lemak.

Berdasarkan evaluasi hasil pemeriksaan darah, pengamatan lingkungan, dan wawancara dengan masyarakat diperoleh hasil bahwa tekanan darah dan gula darah merupakan faktor penentu kesehatan yang harus mendapat perhatian. Pola konsumsi makanan dan sehat merupakan materi yang menjadi konsentrasi program penyuluhan selanjutnya. Selain itu juga faktor lingkungan terutama untuk menurunkan tingkat stres akibat temperatur dan dan keterbatasan oksigen. Berikut ini adalah materi yang diberikan kepada pertemuan ke dua (25 Maret 2018)

\section{HINDARI STROKE DAN AMNESIA DENGAN BERKEBUN MINI}
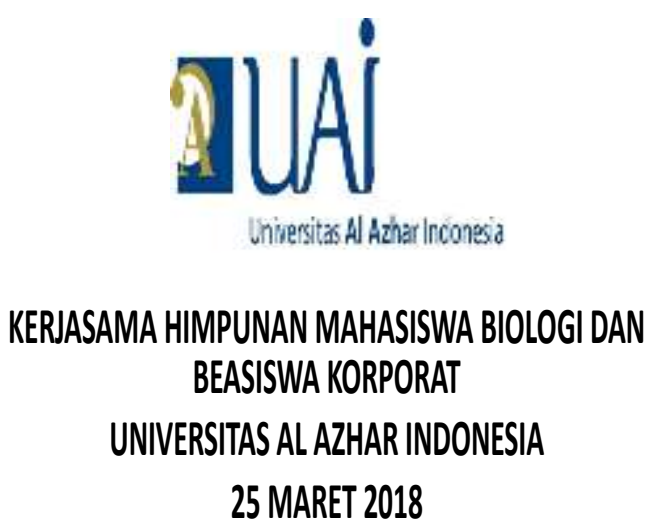

Pada pertemuan ke dua selain diberikan metode untuk menurunkan temperatur dan meningkatkan jumlah oksigen di sekitar pemukiman dengan lahan terbatas. Selain itu dilakukan pengukuran tekanan darah untuk mengevaluasi sejauh mana penyuluhan mengenai pola makanan sehat yang harus dikonsumsi dengan penghasilan yang terbatas mampu dimengerti para ibu (Gambar 5).

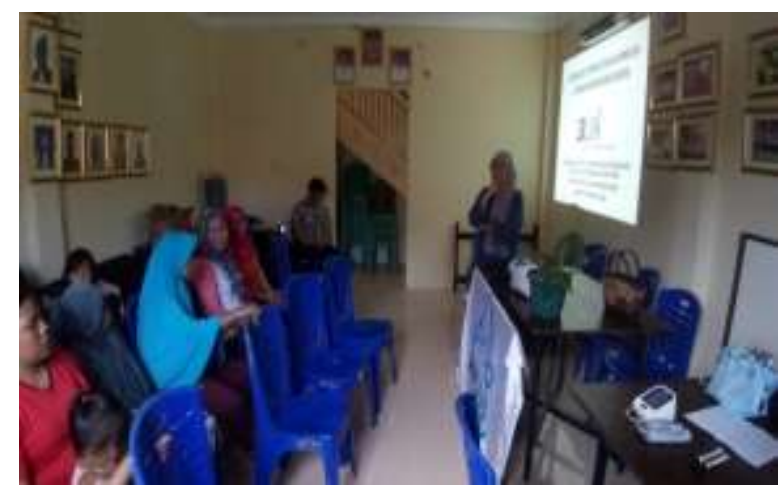

Gambar 5. Para ibu antusis mendengarkan penyuluhan mengenai pengaruh temperature dan sirkulasi terhadap stroke

Selanjutnya di akhir pertemuan para ibu juga diberikan tanaman-tanaman yang dapat ditanam disekitar rumah yang tidak memerlukan lahan yang luas. (Gambar 6)

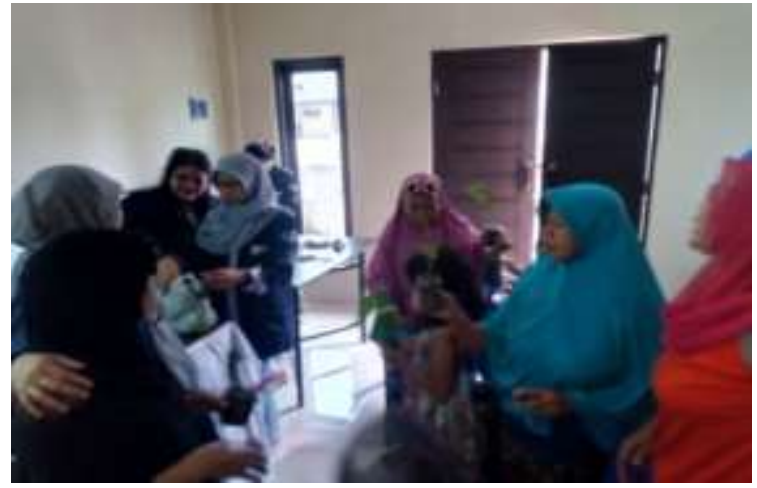

Gambar 6. Para ibu antusis menerima pemberian tanaman untuk ditanam di sekitar rumah

Berikut adalah hasil pengukuran tekanan darah sebelum dan setelah penyuluhan seperti pada Tabel 3.

Tabel 3. Tekanan darah rata-rata pada wanita

\begin{tabular}{cc}
\hline Pertemuan & Tekanan darah rata-rata \\
\hline 14-Jan-18 & $140,9655 / 82,68 \mathrm{~mm} \mathrm{Hg}$ \\
\hline $\mathbf{2 5}-$ Mar-18 & $\mathbf{1 3 4 , 1 5 0 0 / 8 1 , 3 0 ~} \mathbf{~ m ~ H g}$ \\
\hline
\end{tabular}

Data menunjukkan adanya penurunan tekanan darah sistol yaitu 6,8155 poin dan diastole 1,38 point, akan tetapi penurunan belum mencapai batas normal (Tabel 3). Hasil wawancara dengan para ibu mengenai pola makan ternyata belum dapat menghilangkan 
kebiasaan makan ikan asin atau mie instant tapi hanya mengurangi konsumsi.

\section{SIMPULAN DAN SARAN}

Tekanan darah pada wanita berusia 30-50 tahun dan di atas 50 tahun menunjukkan angka diatas rata-rata normal sedangkan gula darah, kolesterol, dan asam urat menunjukan hasil nilai yang normal. Penyuluhan mengenai upaya preventif berkala mengenai kesehatan dan hidup sehat masih perlu dilanjutkan.

\section{UCAPAN TERIMAKASIH}

Terimakasih kami sampaikan kepada Lembaga Pengelitian dan Pengabdian Masyarakat (LP2M) UAI yang telah mendanai pelaksanaan pengabdian masyarakat. Terimakasih juga kami sampaikan kepada Himpinan Mahasiswa Bioteknologi UAI yang telah membantu dan berperan aktif dalam penyuluhan

\section{DAFTAR PUSTAKA}

Choi, H. K., D. B. Mount, and A. M. Reginato. (2005). Pathogenesis of Gout. Ann Intern Med. 143: 499-516.

Ghani L, Mihardja LK, Delima. (2016). Dominant Risk Factors of Stroke in
Indonesia. Buletin Penelitian Kesehatan. 44(1): 49-58.

Hafid MA. (2014). Hubungan Riwayat Hipertensi dengan Kejadian Stroke di RSUP Dr. Wahidin.

Kozier, B., Erb, G., Berman, A., Snyder, J.S., (2010). Fundamentals Of Nursing Concepts, Process, and Practice. EGC. Jakarta

Lanny Sustrani, dkk. (2004). Hipertensi, PT. Gramedia Pustaka Utama, Jakarta.

Manurung M, Diani N, Agianto. (2015). Analisis Faktor Risiko Stroke pada Pasien Stroke Rawat Inap di RSUD Banjarbaru. 3(1): 74-85.

Mehrpour, M. Khouzan, M., Najimi, N., Motamed., M.R. Fereshtehnejad, S.M. (2012). Med. J Islam Repub Iran 26 (2) 6672.

Sulansi. (2015). Stroke menurut Presepsi Pasien di RSUD Ende. Surya. 7(3): 22-30.

Tun, NN., Arunagirinathan, G, Munshi, S., Poppachan. (2017). World J. Diabetes. 8(6):235-248

WHO, (1988). Task Force on Stroke and other Cerebrovascular Disorder. America: World Health Organization.

World Health Organization. Stroke, Cerebrovascular Accident. http://www.who.int/topics/cerebrovascular _accident/en 